\title{
BIOMETRICS OF JUVENILE RUFFS (Philomachus pugnax) MIGRATING IN AUTUMN THROUGH THE PUCK BAY REGION (N POLAND)
}

\author{
Włodzimierz Meissner and Piotr Zięcik
}

\begin{abstract}
Meissner W., Zięcik P. 2005. Biometrics of juvenile Ruffs (Philomachus pugnax) migrating in autumn through the Puck Bay region (N Poland). Ring 27, 2: 189-196.

Between 1983 and 2001, altogether 593 juvenile Ruffs were caught and measured during autumn migration in Puck Bay region. The wing length is the best predictor of sex in juvenile Ruffs. Relatively small differences between sexes in bill and nalospi length imply that males and females forage in a similar manner. However, longer legs in males allow them to forage in deeper water than females.

The comparison of biometrics of juvenile Ruffs caught in different regions indicates that Ruffs from western populations are larger than their conspecifics breeding farther to the east. Slight decrease of mean measurements within the season in juveniles trapped in Puck Bay suggests that Ruffs from more western breeding areas pass study area earlier followed by birds originating further east.

Body mass adjusted for the size increased significantly along the season in males and in females. Thus, similarly to some other juvenile waders, Ruffs that stopped in Puck Bay region migrated with small energetic reserves. However, later migrating birds of both sexes had larger energetic stores than earlier migrants, which could allow them to make longer nonstop flights.
\end{abstract}

W. Meissner, Avian Ecophysiology Unit, Department of Vertebrate Ecology and Zoology, University of Gdańsk, Legionów 9, PL-80-441 Gdańsk, Poland,

E-mail: w.meissner@univ.gda.pl;

P. Zięcik, Kasprowicza 5, PL-81-379 Gdynia, Poland, E-mail: piotrek@tbop.org.pl

Key words: Ruff, autumn migration, biometrics, energetic reserves, Puck Bay.

\section{INTRODUCTION}

Ruffs pass numerously the European inland during autumn and spring migration (Glutz von Blotzheim et al. 1975). Dynamics of autumn migration have been depicted for many sites in Europe (e.g. Harengerd et al. 1973, Winkler and Herzig-Straschil 1981, Kowalski 1985, Meissner and Sikora 1985, Sauvage 2000, Wil- 
niewczyc et al. 2001). Nevertheless, the published data on biometrics of this species are scarce. Results of some investigations suggest that birds from eastern and western parts of breeding area differ in biometrics (Glutz von Blotzheim et al. 1975, Schmitt and Whitehouse 1976, OAG Münster 1990). Thus, the analysis of biometrics of birds caught in a given area during migration may help in understanding migration routes of different populations.

The main aim of this study is to describe the biometrics of Ruffs migrating through the Puck Bay in autumn with special emphasis on amount of energetic reserves carried by birds passing the study area earlier and later within the migration period. Due to small sample size of caught adults only data on juveniles were taken into account.

\section{MATERIAL AND METHODS}

Birds were caught between 1983 and 2001 mainly in walk-in traps (Meissner 1998) placed on the Gulf of Gdańsk coast at three sites: at Jastarnia, in the Reda mouth and at Rewa (Meissner and Remisiewicz 1998) (Fig. 1). Mist-nets were used occasionally. Every year the fieldwork started in mid-July and finished at the end of September. This period covered almost the whole term of juvenile Ruff migration in the study area (Meissner and Sikora 1995).



Fig. 1. Localisation of the ringing sites of WRG KULING within a study area: RE - Rewa, RM - Reda mouth, JA - Jastarnia

Each juvenile Ruff was sexed (Prater et al. 1977) and the following measurements were taken: wing length (Evans 1986), total head length (Green 1980), bill length and nalospi length (Prater et al. 1977), tarsus length (Svensson 1992) and tarsus plus toe length (Piersma 1984). Before 1991, total head length and bill length 
were measured to the nearest $1 \mathrm{~mm}$ with stopped ruler, later on with callipers to the nearest $0.1 \mathrm{~mm}$. To combine less and more precise measurements, the latter were rounded to the nearest $1 \mathrm{~mm}$. Birds were also weighed with accuracy of $2 \mathrm{~g}$.

In total 210 males and 383 females of juvenile Ruffs were ringed. Every year the accuracy and the repeatability of measurements taken by different ringers were checked as described by Busse (2000). There were no significant differences in any of measurements between birds caught in Jastarnia, Rewa and in Reda mouth (ANOVA: $p>0.05$ ), thus sample from these three sites were combined.

The body mass of each bird was adjusted for body size. Principal component analysis ( $P C A)$ was conducted separately for males and females, on wing length, total head length and tarsus length for obtaining a single value representing overall size of the bird. Only one significant factor was extracted with loadings of 0.779 and 0.678 for wing length, 0.842 and 0.852 for total head length and 0.829 and 0.835 for tarsus length in females and males, respectively. These three measurements were taken simultaneously in 219 females and in 67 males. The equations for calculating size factor were as follows:

where:

$$
\begin{aligned}
& \text { for females: } B S=0.389 W L+0.420 T H L+0.414 T L, R^{2}=0.67 \\
& \text { for males: } B S=0.360 W L+0.452 T H L+0.443 T L, R^{2}=0.63
\end{aligned}
$$

$B S$ - body size,

$W L$ - wing length,

$T H L$ - total head length,

$T L$ - tarsus length.

Subsequently, body mass was regressed against calculated body size. The following regression lines equation were obtained:

$$
\begin{aligned}
& \text { for females: } B M=2.41 B S+94.11 \\
& \text { for males: } B M=2.00 B S+105.94
\end{aligned}
$$

where:

$B M-$ body mass.

The slopes of these equations were applied for calculating size-adjusted body mass $(B M A)$ :

$$
\begin{aligned}
& \text { for females: } B M A=B M+2.41(92.22-B S) \\
& \text { for males: } B M A=B M+2.00(122.59-B S)
\end{aligned}
$$

where 92.22 and 122.59 are the mean size factor calculated respectively for all males and females in the sample.

All other statistical methods used in this study followed Zar (1996). The analysis was done in STATISTICA 6.0 software (StatSoft 2001). 


\section{RESULTS}

Males are larger and heavier than females (Table 1). Beside body mass, the highest relative difference between males and females appeared in wing length and in tarsus length. There was no overlap between both sexes in distributions of wing length, tarsus plus toe length and total head length (Fig. 2). Only tarsus plus toe length showed clear bimodality in both sexes.

Table 1

Mean measurements and unadjusted body mass of juvenile males and females of the Ruff caught in Puck Bay region during autumn migration

\begin{tabular}{|c|c|c|c|c|c|c|c|}
\hline \multirow{2}{*}{ Measurement } & \multicolumn{3}{|c|}{$\sigma^{7} \sigma^{\prime \prime}$} & \multicolumn{3}{|c|}{ 우 } & \multirow{2}{*}{$\begin{array}{c}\text { Relative } \\
\text { difference } \\
(\%)\end{array}$} \\
\hline & Mean & $S D$ & $N$ & Mean & $S D$ & $N$ & \\
\hline Total head length & 70.4 & 1.70 & 209 & 61.2 & 1.46 & 379 & 14.9 \\
\hline Bill length & 35.2 & 1.49 & 203 & 30.8 & 1.28 & 376 & 14.4 \\
\hline Nalospi & 27.5 & 1.43 & 65 & 24.6 & 1.02 & 106 & 11.8 \\
\hline Wing length & 190.5 & 3.54 & 210 & 159.3 & 3.05 & 383 & 19.5 \\
\hline Tarsus + toe length & 87.9 & 2.42 & 68 & 75.5 & 2.12 & 120 & 16.5 \\
\hline Tarsus length & 50.05 & 1.90 & 103 & 42.19 & 1.64 & 220 & 18.6 \\
\hline Unadjusted body mass & 158.6 & 25.39 & 200 & 96.9 & 14.82 & 374 & 63.7 \\
\hline
\end{tabular}

The tarsus length in males decreased along the season $(r=-0.30, N=100$, $p<0.05)$. Other measurements also showed reduction towards the end of migration period, but correlation coefficients were not statistically significant $(p>0.05$ in all cases). In females tarsus length $(r=-0.25, N=217, p<0.05)$, wing length $(r=-0.18, p<0.05)$ and bill length $(r=-0.27, N=370, p<0.05)$ decreased slightly, but significantly along the season.

Adjusted body mass in birds caught first time increased significantly along the season in males $(r=0.39, N=97, p<0.05)$ and in females $(r=0.41, N=211$, $p<0.05)$. There were no significant difference between these two correlation coefficients in males and females (test for two correlation coefficients: $Z=0.26$, $p>0.05)$. The slope of linear regression in males (0.43) and females (0.40) also did not differ significantly (test between two regression coefficients: $t=0.62, p>0.05$ ). Thus, the increase of adjusted body mass in males and in females arriving to Puck Bay was similar.

\section{DISCUSSION}

The capability of effective flight can be related to wing area and body mass. Larger and heavier males need greater wings to maintain good aerodynamic prop- 

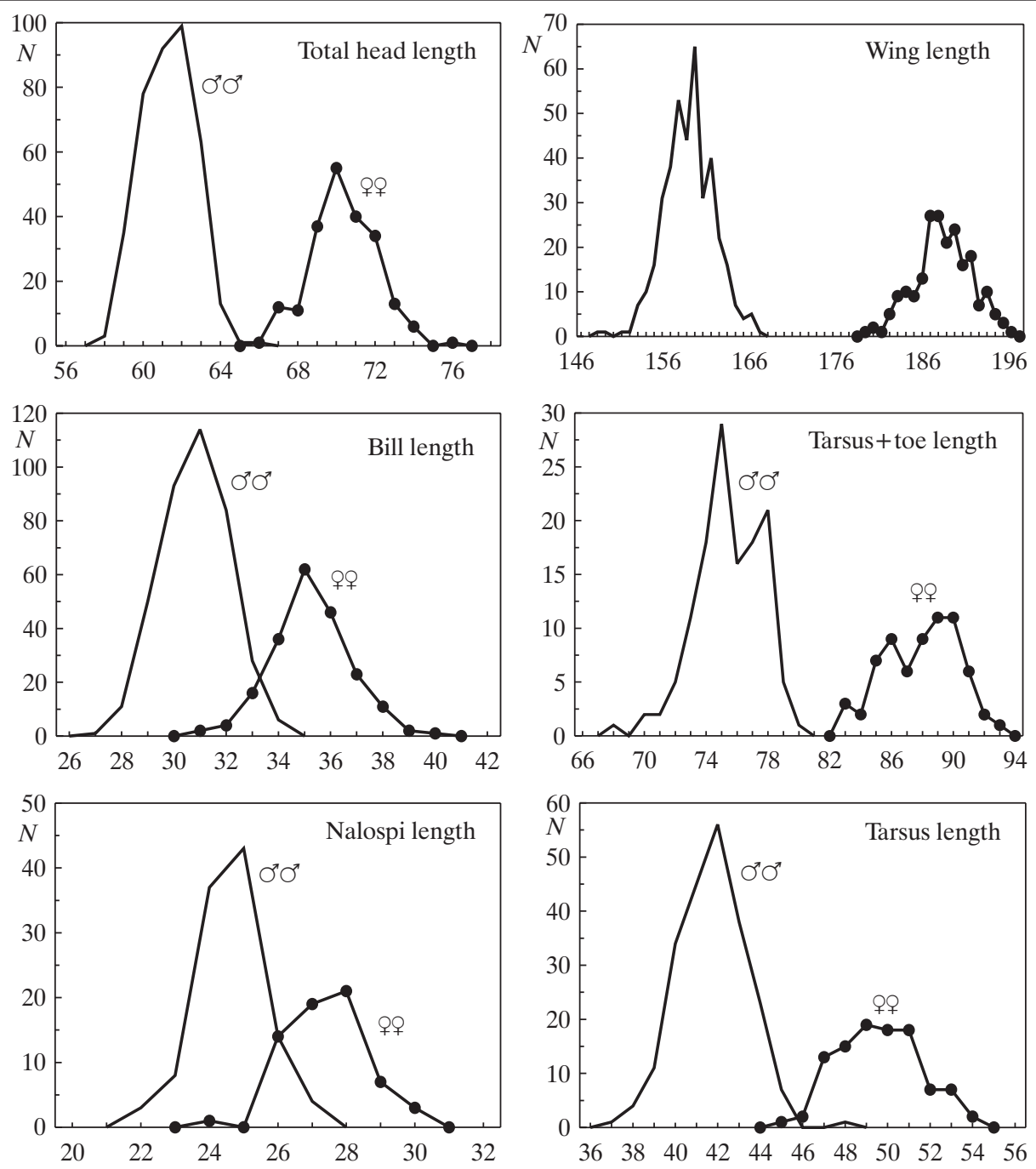

Fig 2. Frequency distributions of different measurements of juvenile Ruffs. Data from Jastarnia, Rewa and Reda river mouth were combined.

erties for long-distance migration. The wing shape in both sexes of Ruff is similar. Thus, the longer wings of males create larger wing area and hence the wing length is the best predictor of sex in Ruffs (Prater et al. 1977, OAG Münster 1990, this study). Relatively small differences between sexes in bill and nalospi length imply that males and females forage in similar manner. Hoerschelmann (1972) suggests that the shape and structure of Ruff's bill strongly indicates that this species is typical visual forager. In waders the leg length is positively correlated with the depth of water in which birds search for food (Baker 1979) and longer legs in Ruff males allow them to forage in deeper water in comparison to females. Hence, due to this differ- 
ence both sexes could segregate themselves during foraging and avoid intraspecific concurrence.

The mean wing and bill lengths of Ruffs wintering in southern and eastern Africa are somewhat smaller than in birds measured in various sites in Europe (Table 2). Ringing recoveries indicate that birds ringed in Kenya and in South Africa belong to breeding population from central and eastern Siberia, whereas majority of those passing Western Europe in autumn spend winter in western Africa (Pearson 1981, Lebedeva and Dobrynina 1985, Underhill et al. 1999). Hence, it appears that Ruffs from western populations are larger than their conspecifics breeding farther to the east. Slight decrease of mean measurements in juveniles within the season detected in the study region suggests that Ruffs from more western breeding areas pass Puck Bay earlier followed by birds originating farther east. Comprehensive study of OAG Münster (1990) also showed continuous decrease of bill length averages of juveniles migrating in subsequent five-day periods.

Table 2

Comparison of average measurements of juvenile Ruffs caught in different European and African localities

\begin{tabular}{|c|c|c|c|c|c|c|c|}
\hline \multirow{2}{*}{ Area } & \multicolumn{2}{|c|}{$\begin{array}{l}\text { Wing length } \\
\qquad(\mathrm{mm})\end{array}$} & \multicolumn{2}{|c|}{$\begin{array}{l}\text { Bill length } \\
\quad(\mathrm{mm})\end{array}$} & \multicolumn{2}{|c|}{$\begin{array}{l}\text { Tarsus length } \\
\quad(\mathrm{mm})\end{array}$} & \multirow{2}{*}{ Source } \\
\hline & $0^{\prime \prime}$ & qQج & $\sigma^{\prime \prime}$ & 우 & $\sigma^{7} \sigma^{\prime \prime}$ & Q⿻丷 & \\
\hline Puck Bay (Poland) & 190.6 & 159.3 & 35.2 & 30.8 & 50.1 & 42.2 & This study \\
\hline Münster (Germany) & 190.2 & 159.3 & 34.9 & 30.5 & 50.3 & 42.8 & OAG Münster 1990 \\
\hline Ägelsee (Switzerland) & 191.0 & 159.4 & 35.0 & 30.7 & & & Glutz von Blotzheim et al. 1975 \\
\hline Lincolnshire (UK) & & & 35.3 & 31.1 & & & Glutz von Blotzheim et al. 1975 \\
\hline Kenya & 187.4 & 156.3 & & & & & Pearson $1981^{1}$ \\
\hline South Africa & 184.5 & 154.4 & 34.3 & 30.2 & & & Schmitt and Whitehouse $1976^{2}$ \\
\hline
\end{tabular}

only birds caught from August to December - recalculated from Table 7

2 adults and juveniles combined

The mean unadjusted body mass of birds caught during this study was rather low when comparing with data on this species from other sites during migration (Schmitt and Whitehouse 1976, Pearson 1981, Koopman 1986, Glutz von Blotzheim et al. 1975, OAG Münster 1998). In winter in West Africa juvenile males and females weighed about $170 \mathrm{~g}$ and $100 \mathrm{~g}$, respectively (OAG Münster 1998), which in the case of females is close to mean unadjusted body mass obtained in this study. Thus, similarly to some other juvenile waders, Ruffs stopped in Puck Bay region migrated with small energetic reserves (Meissner 1996, 1997a, 2003). However, adjusted body mass increased along the season in similar rate in males and females. It means that later migrating birds of both sexes had larger energetic stores than earlier migrants. The extra fat reserves allow to make longer non-stop flight (Meissner 1997b), but also might be treated as a kind of insurance against difficulties later in the season when the risk of severe weather is greater (Pienkowski et al. 1979, Kaiser and Gillingham 1981). 


\section{ACKNOWLEDGEMENTS}

This study was conducted by the Waterbird Research Group KULING (paper no 114). We are grateful to all colleagues from WRG KULING and to many volunteers who helped in collecting the data.

\section{REFERENCES}

Baker C.M. 1979. Morphological correlates of habitat selection in a community of shorebirds (Charadriiformes). Oikos 33: 121-126.

Busse P. (Ed.). 2000. Bird station manual. SE European Bird Migration Network, Gdańsk Univ. Press, Gdańsk.

Evans P.R. 1986. Correct measurements of the wing length of waders. Wader Study Group Bull. 48: 11.

Glutz von Blotzheim U.N., Bauer K.M., Bezzel E. 1975. Handbuch der Vögel Mitteleuropas. vol. 6. Akademiche Verlag, Wiesbaden.

Green G.H. 1980. Total head length. Wader Study Group Bull. 29: 18.

Harengerd M., Prünte W., Speckmann M. 1973. Zugphänologie uns Status der Limikolen in den Rieselfeldern der Stadt Münster. 2 Teil: Calidris bid Phalaropus. Vogelwelt 94: 121-146.

Hoerschelmann H. 1972. Schnabelform und Nahrungserwerb bei Schnepfenvögeln (Charadriidae und Scolopacidae). Z. Wiss. Zool. 185: 105-121.

Kaiser G.W., Gillingham M. 1981. Some notes on seasonal fluctuations in the weight of Dunlin Calidris alpina on the Fraser river delta, British Columbia. Wader Study Group Bull. 31: 46-48.

Koopman K. 1986. Primary moult and weight changes of Ruffs in the Netherlands in relation to migration. Ardea 74: 69-77.

Kowalski O. 1985. Zugphänologie und Bruten von Limikolen auf den Spülflachen Stau und Kattegatt in Lübeck. Corax 11: 45-69.

Lebedeva M.I., Dobrynina I.N. 1985. [Ruff-Philomachus pugnax (L.).] In: Viksne J.A., Michelson H.A. (Eds). [Migration of birds of Eastern Europe and Northern Asia.] Nauka, Moscow: pp. 154-171. (In Russian).

Meissner W. 1996. Timing and phenology of autumn migration of Common Sandpiper (Actitis hypoleucos) at the Gulf of Gdańsk. Ring 18: 59-72.

Meissner W. 1997a. Timing and phenology of autumn migration of Wood Sandpiper (Tringa glareola) at the Gulf of Gdańsk. Ring 19: 75-91.

Meissner W. 1997b. Autumn migration and biometrics of the Common Sandpiper Actitis hypoleucos caught in the Gulf of Gdańsk. Ornis Fenn. 74: 131-139.

Meissner W. 1998. Some notes on using walk-in traps. Wader Study Group Bull. 86: 33-35.

Meissner W. 2003. Biometrics, length of stay and body mass increase of migrating Common Snipes Gallinago gallinago in the Gulf of Gdańsk. Vogelwelt 124: 45-52.

Meissner W., Remisiewicz M. 1998. Wader Studies of the Waterbird Research Group "KULING" in 1983-1998. Ring 20: 21-33.

Meissner W., Sikora A. 1995. Spring and autumn migration of waders (Charadrii) on the Hel Peninsula. Not. Orn. 36: 205-239.

OAG Münster 1990. Zur Biometrie des Kampfläufers Philomachus pugnax während beider Zugphasen. Vogelwelt 111: 2-18.

OAG Münster 1998. Mass of Ruffs Philomachus pugnax wintering in West Africa. Int. Wader Stud. 10: 435-440.

Pearson D.J. 1981. The wintering and moult of Ruffs Philomachus pugnax in the Kenyan Rift Valley. Ibis 123: $158-182$.

Pienkowski M.W., Lloyd C.S., Minton C.D.T. 1979. Seasonal and migrational weight changes in Dunlin. Bird Study 26: 134-148. 
Piersma T. 1984. International wader migration studies along the East Atlantic Flyway during spring 1985. Final announcement of a Wader Study Group project. Wader Study Group Bull. 42: 5-9.

Prater A.J., Marchant J.H., Vuorinen J. 1977. Guide to the identification and ageing of Holarctic waders. BTO Tring.

Sauvage A. 2000. Les limicoles sur les bassins de decantation de la sucrerie d'Attigny, dans les vallees de l'Aisne et la chires (Ardennes): phenologie de la migration, reproduction et hivernage. I'Orfraie, Special issue: $220 \mathrm{pp}$.

Schmitt M.B., Whitehouse P.J. 1976. Moult and mensural data of Ruff on the Witwatersrand. Ostrich 47: 179-190.

StatSoft, Inc. 2001. STATISTICA (data analysis software system). version 6. www.statsoft.com.

Svensson L. 1992. Identification Guide to European Passerines. Stockholm.

Underhill L.G., Tree A.J., Oschadleus H.D., Parker V. 1999. Review of Ringing Recoveries of Waterbirds in Southern Africa. Avian Demography Unit, University of Cape Town.

Wilniewczyc P., Szczepaniak W., Zięcik P., Jantarski M. 2001. Birds of fishponds in Górki and surrouding area. Kulon 6: 3-61.

Winkler H., Herzig-Straschil B. 1981. Die Phänologie der Limikolen im Seewinkel (Burgenland) in den Jahren 1963 bis 1972. Egretta 24: 47-69.

Zar J.H. 1996. Biostatistical Analysis. Prentice-Hall, London. 